\title{
Molecular characterization and RAPD analysis of Juniperus species from Iran
}

\author{
J. Kasaian ${ }^{1}$, J. Behravan ${ }^{1,2}$, M. Hassany ${ }^{1}$, S.A. Emami ${ }^{2}$, F. Shahriari ${ }^{3}$ and \\ M.H. Khayyat ${ }^{2}$ \\ ${ }^{1}$ Biotechnology Research Center, Mashhad University of Medical Sciences, \\ Mashhad, Iran \\ ${ }^{2}$ Faculty of Pharmacy, Mashhad University of Medical Sciences, Mashhad, Iran \\ ${ }^{3}$ Faculty of Agriculture, Ferdowsi University of Mashhad, Mashhad, Iran \\ Corresponding author: J. Kasaian \\ E-mail: kasaeeianj1@mums.ac.ir
}

Genet. Mol. Res. 10 (2): 1069-1074 (2011)

Received August 17, 2010

Accepted December 27, 2010

Published June 7, 2011

DOI 10.4238/vol10-2gmr1021

\begin{abstract}
The genus Juniperus L. (Cupressaceae), an aromatic evergreen plant, consists of up to 68 species around the world. We classified five species of Juniperus found in Iran using molecular markers to provide a means for molecular identification of Iranian species. Plants were collected (three samples of each species) from two different provinces of Iran (Golestan and East Azarbayejan). The DNA was extracted from the leaves using a Qiagen Dneasy Plant Mini Kit. Amplification was performed using 18 ten-mer RAPD primers. Genetic distances were estimated based on 187 RAPD bands to construct a dendrogram by means of unweighted pair group method of arithmetic means. It was found that $J$. communis and J. oblonga were differentiated from the other species. Genetic distance values ranged from 0.19 (J. communis and J. oblonga) to 0.68 (J. communis and J. excelsa). Juniperus foetidissima was found to be most similar to J. sabina. Juniperus excelsa subspecies excelsa and $J$. excelsa subspecies polycarpos formed a distinct group.
\end{abstract}

Key words: Juniperus; RAPD markers; DNA amplification; Genetic distance; Iran 


\section{INTRODUCTION}

The genus Juniperus L. (Cupressaceae) consists of up to 68 species around the world. It is an aromatic, drought-resistant plant that is found in mountainous parts of the northern hemisphere (altitude: 500-3000 m) except for some species in Africa (Adams and Pandey, 2003).

The Juniperus species of Iran mainly consist of five species with two vegetation forms (tree or shrub): J. communis L., J. oblonga M.B., J. sabina L., J. foetidissima Willd., and $J$. excelsa M.B. with two subspecies namely $J$. excelsa M.B. subspecies excelsa and $J$. excelsa M.B. subspecies polycarpos (K. Koch) Takhtajan. They are widely spread evergreen plants that grow in several provinces of Iran (Khorasan, Golestan, Semnan, Mazandaran, Gilan, Azarbayejan, Ardabil, Fars, Yazd, Kerman, and Hormozgan). In Iran the key character separating J. communis from other species is the morphological characterization. It is a shrub, $2.2 \mathrm{~m}$ tall, multistemmed, decumbent, crown generally depressed, altitude $2063 \mathrm{~m}$. J. oblonga is a shrub to small tree, 1-4 m, decumbent-upright, growing in East Azarbayejan Province, altitude $1500 \mathrm{~m}$. This seems to imply that these species possess similarities, although they grow in distinct regions. $J$. sabina is a shrub, 2-3 m, prostrate, growing in Golestan Province, altitude $2050 \mathrm{~m}$. J. foetidissima is a tree, up to $16 \mathrm{~m}$, growing in East Azarbayejan Province, altitude $1400 \mathrm{~m}$. $J$. excelsa subspecies excelsa is a monoecious plant with taxonomic problems in Iran. $J$. excelsa subspecies polycarpos is a tree, up to $25 \mathrm{~m}$, growing in different parts of Iran, altitude 500-3000 m (Emami et al., 2007). DNA fingerprinting studies were used alone or together with the leaf volatile oils for Juniperus classification (Adams, 2000a,b,c; Adams et al., 2006). An isoenzyme analysis was performed on 109 individuals from 11 populations of $J$. excelsa complex collected from Iran (Hojjati et al., 2009). Random amplified polymorphic DNA (RAPD) markers have also been used to assess differences among Juniper and Cedar cultivars (Hsiang and Huang, 2000).

The objective of the present study was to investigate the ability of RAPD markers to cluster 5 species of Juniperus from Iran.

\section{MATERIAL AND METHODS}

\section{Plant material}

Plant materials were obtained from their main local growth area of Golestan and East Azarbayejan Provinces (Table 1). Fresh leaves were preserved at $-80^{\circ} \mathrm{C}$ using an ultra-low freezer until DNA extraction. Voucher specimens were deposited in the Ferdowsi University of Mashhad Herbarium (FUMH).

\begin{tabular}{|c|c|c|c|c|}
\hline Species & Location & Altitude (m) & Collection date & Voucher No. \\
\hline J. communis & Between Damab and Cephali, Golestan Province & 2063 & Oct. 4, 2002 & FUMH37069 \\
\hline J. excelsa subspecies excelsa & Kelisa Kharabeh, East Azarbayejan Province & $1400-1600$ & Nov. 30, 2002 & FUMH37074 \\
\hline J. excelsa subspecies polycarpos & Chopoughlou Darahsi, East Azerbayejan Province & 1593 & Sept. 21, 2002 & FUMH37065 \\
\hline J. oblonga & $\begin{array}{l}\text { Between Makidi and Vainagh, } \\
\text { East Azerbayejan Province }\end{array}$ & 1500 & July 6,2002 & FUMH37071 \\
\hline J. sabina & Sourkesh, Golestan Province & 2050 & Oct. 3, 2002 & FUMH37072 \\
\hline J. foetidissima & $\begin{array}{l}\text { Between Makidi and Vainagh, } \\
\text { East Azerbayejan Province }\end{array}$ & 1400 & Sept. 23, 2002 & FUMH37067 \\
\hline
\end{tabular}




\section{DNA extraction and polymerase chain reaction (PCR)}

Genomic DNA was extracted from the leaves using the Qiagen Dneasy Plant Mini Kit (Qiagen, Germany). Extracted DNA was quantified by spectrophotometer (Nanodrop ND-1000, USA), at an absorbance level of $260 / 280 \mathrm{~nm}$. The quality was further checked on $0.8 \%$ agarose gel.

Ten-mer primers were purchased from Microsynth (Switzerland). Sequence information for the primers is presented in Table 2.

\begin{tabular}{|c|c|c|c|c|c|}
\hline No. & Oligo name & Sequences 5'-3' & Size (nt) & $\mathrm{MW}(\mathrm{g} / \mathrm{mol})$ & $\operatorname{Tm}\left({ }^{\circ} \mathrm{C}\right)$ \\
\hline 1 & P116 & TACGATGACG & 10 & 3052.2 & 30 \\
\hline 2 & P134 & AACACACGAG & 10 & 3030.0 & 30 \\
\hline 3 & P153 & GAGTCACGAG & 10 & 3077.1 & 32 \\
\hline 4 & P204 & TTCGGGCCGT & 10 & 3035.3 & 34 \\
\hline 5 & P212 & GCTGCGTGAC & 10 & 3044.2 & 34 \\
\hline 6 & P218 & CTCAGCCCAG & 10 & 2973.1 & 34 \\
\hline 7 & P239 & CTGAAGCGGA & 10 & 3077.1 & 32 \\
\hline 8 & P249 & GCATCTACCG & 10 & 2988.2 & 32 \\
\hline 9 & P250 & CGACAGTCCC & 10 & 2973.1 & 34 \\
\hline 10 & P265 & CAGCTGTTCA & 10 & 3003.3 & 30 \\
\hline 11 & P327 & ATACGGCGTC & 10 & 3028.2 & 32 \\
\hline 12 & P338 & CTCTGGCGGT & 10 & 3035.3 & 34 \\
\hline 13 & P346 & TAGGCGAACG & 10 & 3077.1 & 32 \\
\hline 14 & P347 & TTGCTTGGCG & 10 & 3050.4 & 32 \\
\hline 15 & P375 & CCGGACACGA & 10 & 3022.0 & 34 \\
\hline 16 & P391 & GCGAACCTCG & 10 & 3013.1 & 34 \\
\hline 17 & P413 & GAGGCGGCGA & 10 & 3118.0 & 36 \\
\hline 18 & P431 & CTGCGGGTCA & 10 & 3044.2 & 34 \\
\hline
\end{tabular}

Size $(\mathrm{nt})=$ number of nucleotides in a primer; $\mathrm{MW}=$ molecular weight in gram per mol; $\mathrm{Tm}=$ melting temperature.

PCR was performed in a volume of $15 \mu \mathrm{L}$ containing $50 \mathrm{mM}$ Tris- $\mathrm{HCl}, \mathrm{pH} 9,2.0 \mathrm{mM}$ $\mathrm{MgCl}_{2}, 0.01 \%$ gelatin and $0.1 \%$ Triton X-100, $0.2 \mathrm{mM}$ of each dNTP, $0.36 \mu \mathrm{M}$ of each primer, $0.3 \mathrm{ng}$ genomic DNA, $15 \mathrm{ng}$ BSA and 0.6 U Taq DNA polymerase (Fermentas, Germany). A control PCR tube containing all components, but no genomic DNA, was performed with each primer to check for contamination. DNA amplification was performed in a Programmable Thermal Cycler (Techne Research Inc., UK). The thermal cycle included: $94^{\circ} \mathrm{C}(1.5 \mathrm{~min})$ for initial strand separation, then 40 cycles of $38^{\circ} \mathrm{C}(2 \mathrm{~min}), 72^{\circ} \mathrm{C}(2 \mathrm{~min}), 91^{\circ} \mathrm{C}(1 \mathrm{~min})$. Two additional steps were used: $38^{\circ} \mathrm{C}(2 \mathrm{~min})$ and $72^{\circ} \mathrm{C}(5 \mathrm{~min})$ for final extension (Asili et al., 2010). Amplification products were loaded onto $1 \%$ agarose gels (Sigma, Germany). DNA ladder (100 bp; Fermentas, Germany) was loaded on the last lane of each gel.

The presence or absence of each band was scored as 1 or 0 , respectively. Bands that were inconsistent in replicate analyses were not scored. Bands that occurred once or did not show fidelity within the two samples of each taxon were eliminated. Binary matrix was used to estimate genetic similarities and distances between pairs, by employing Dice index (Nei and $\mathrm{Li}, 1979)$. These similarity coefficients were used to generate a dendrogram by means of the unweighted pair group method of arithmetic means (UPGMA).

\section{RESULTS AND DISCUSSION}

One hundred and eighty-seven RAPD bands were detected (Figure 1). 


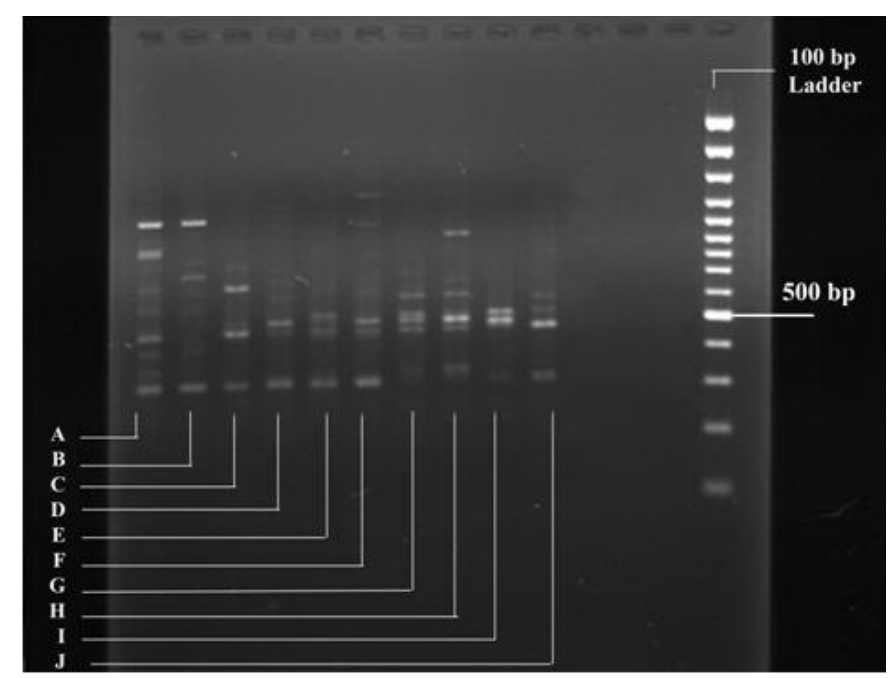

Figure 1. RAPD fingerprints with the use of primer P204. Lane $A=$ Juniperus communis (female); lane $B=J$. communis (male); lane $C=J$. excelsa subspecies polycarpos (female); lane $D=J$. excelsa subspecies polycarpos (male); lane $E=J$. sabina (female); lane $F=J$. sabina (male); lane $G=J$. foetidissima (female); lane $H=J$. foetidissima (male); lane $I=J$. oblonga; lane $J=J$. excelsa subspecies excelsa.

The analysis of the RAPD bands were generated by 18 random primers and yielded an average of 10.3 bands/primer. Genetic similarities among five Juniperus species using RAPD primers are presented in Table 3.

Table 3. Genetic distance values obtained for 6 Iranian Juniperus.

\begin{tabular}{lcccccc}
\hline Species & 1 & 2 & 3 & 4 & 5 & 6 \\
\hline 1 & $*$ & $*$ & & & & \\
2 & 0.35 & 0.46 & $*$ & & & \\
3 & 0.54 & 0.57 & 0.44 & $*$ & $*$ & $*$ \\
4 & 0.51 & 0.62 & 0.57 & 0.52 & 0.62 & $* 33$ \\
5 & 0.19 & 0.13 & 0.38 & 0.33 & \\
6 & 0.68 & $J$
\end{tabular}

$1=J$. communis $; 2=J$. excelsa subspecies polycarpos $; 3=J$. sabina $; 4=J$. foetidissima $; 5=J$. oblonga $; 6$ $=J$. excelsa subspecies excelsa.

Genetic distance values between five Juniperus species ranged from 0.214 (J. excelsa subspecies polycarpos and $J$. excelsa subspecies excelsa) to 0.733 (J. communis and J. excelsa subspecies excelsa). The dendrogram constructed is presented in Figure 2.

This analysis shows two major groups. The first group contains $J$. communis and $J$. oblonga. The second large group includes $J$. excelsa subspecies excelsa, J. excelsa subspecies polycarpos, J. sabina, and J. foetidissima, that separate into two subgroups.

This study has compared all species of Juniperus in Iran. Species that are separated by even minute morphological character differences (J. excelsa subspecies excelsa, J. foetidissima and $J$. excelsa subspecies polycarpos) were found to possess considerable DNA differences.

J. sabina is native to the mountains of central and southern Europe and western and central Asia, from eastern Spain to eastern Siberia, typically growing at altitudes of $1000-3300 \mathrm{~m}$. It is very 


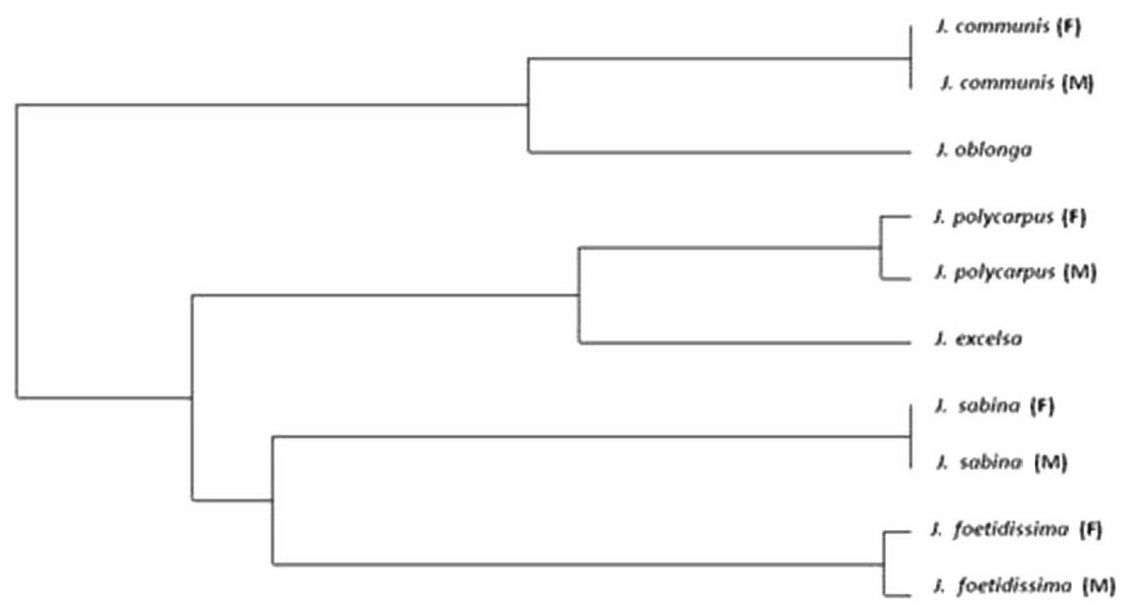

Figure 2. UPGMA dendrogram generated based on the cluster analysis of 187 RAPD bands of five species of Juniperus.

widely distributed from Spain through Europe to Siberia. It is generally a small shrub, less than $1 \mathrm{~m}$ in height and ranging from 1-2 $\mathrm{m}$ in width. However, in the Sierra Nevada of Spain, it forms a prostrate shrub on rocky areas and in Mongolia it occurs as a prostrate plant on sand dunes (Adams and Schwarzbach, 2006). Iranian J. sabina is a shrub, up to 2-3 m tall, prostrate, and occurs at an altitude of $2050 \mathrm{~m}$. DNA fingerprinting revealed that J. sabina from the Eastern hemisphere is a multiseeded Juniperus, clusters weakly with J. semiglobosa-talassica and J. jarkendensis, and is distinct from $J$. excelsa, J. excelsa var. polycarpos and $J$. foetidissima (Adams, 1999). There was support (67\%) that $J$. sabina from the Mongolian sand dunes is a distinct taxon (Adams and Schwarzbach, 2006). In this study, DNA fingerprinting of Iranian Junipers revealed that J. sabina clusters weakly with $J$. foetidissima (Figure 2). Researchers have suggested that $J$. sabina acts as a nurse plant for J. communis (Verdu et al., 2004). J. foetidissima is a medium-sized tree reaching 6-25 $\mathrm{m}$ in height, with a trunk up to $2.5 \mathrm{~m}$ in diameter and two forms of leaves. $J$. excelsa subspecies excelsa is a large tree reaching 6-20 m in height. It is largely monoecious, often occurs together with $J$. foetidissima. J. excelsa subspecies excelsa (Greek Juniper) is a Juniper found throughout the Eastern Mediterranean, from Greece across Turkey to Syria and the Caucasus Mountains. J. excelsa subsp polycarpos, known as the Persian Juniper, occurs in the Alborz and other mountains of Iran and to the east to northwestern Pakistan. Some botanists treat J. polycarpos syn. J. macropoda as a distinct species (Verdu et al., 2004). Iranian J. excelsa subspecies excelsa and J. foetidissima have the same characters as these species in other countries, but the Iranian $J$. excelsa subspecies excelsa is a monoecious plant. J. excelsa subspecies polycarpos of Iran is very similar to the $J$. excelsa subspecies excelsa in terms of vegetation characters, such as shape, type of leaves, seeds and height, but it is largely some older dioecious data sets that support the recognition of the $J$. excelsa subspecies polycarpos as a subspecies of $J$. excelsa. In the Balochistan Province, the Pakistan Juniper initially was called $J$. excelsa, but later it was suggested that it should be referred to as $J$. turcomanica var. seravschanica not $J$. excelsa or J. macropoda. Adams showed that clustering based on 126 RAPDs revealed three groups: $J$. excelsa, J. procera and the J. polycarpos-seravschanica-turcomanica complex. These three groups were clustered at about the same level. This supports the concept of three species: J. excelsa, J. polycarpos and J. procera. This was in contrast to his previous article. The RAPD analysis revealed that $J$. foetidissima and $J$. excelsa are distinct. J. foetidissima is clus- 
tered with J. sabina. J. excelsa closely clustered with J. polycarpos (Adams, 1999).

J. communis and its varieties have been studied. One of them was J. communis var. oblonga collected from Lake Sevan, Armenia. Based on 191 RAPD bands, they found that there was little evidence to support the recognition of J. communis var. oblonga (Adams and Pandey, 2003).

Adams (1999) explained that the most surprising aspect of his research has been the divergences of morphologically near-identical taxa in their terpenoids and DNA fingerprints. He showed that even species separated by minute morphological character differences possess considerable terpenoid and DNA differences, which suggest that evolution proceeds at different rates for different character sets. The use of multiple character sets seems prudent in Juniperus taxonomy and evolutionary studies (Adams, 1999).

It seems that this study is the first complete research on Iranian Juniperus species DNA fingerprinting. The authors believe that further studies need to be based on geographic variation of Juniperus in Iran.

\section{ACKNOWLEDGMENTS}

We would like to thank Professor Robert P. Adams for his valuable advice on the PCR and analysis of the results. Research supported by the Research Council of Mashhad University of Medical Sciences, Iran.

\section{REFERENCES}

Adams RP (1999). Systematics of multi-seeded eastern hemisphere Juniperus based on leaf essential oils and RAPD DNA fingerprinting. Biochem. Syst. Ecol. 27: 709-725.

Adams RP (2000a). Systematics of the one seeded Juniperus of the eastern hemisphere based on leaf essential oils and random amplified polymorphic DNAs (RAPDs). Biochem. Syst. Ecol. 28: 529-543.

Adams RP (2000b). The serrate leaf margined Juniperus (Section Sabina) of the western hemisphere: systematics and evolution based on leaf essential oils and Random Amplified Polymorphic DNAs (RAPDs). Biochem. Syst. Ecol. 28: 975-989.

Adams RP (2000c). Systematics of Juniperus section Juniperus based on leaf essential oils and random amplified polymorphic DNAs (RAPDs). Biochem. Syst. Ecol. 28: 515-528.

Adams RP and Pandey RN (2003). Analysis of Juniperus communis and its varieties based on DNA fingerprinting. Biochem. Syst. Ecol. 31: 1271-1278.

Adams RP and Schwarzbach AE (2006). A new variety of Juniperus sabina from Mongolia: J. sabina var. mongolensis. Phytologia 88: 179-185.

Adams RP, Elizondo MSG, Elizondo MG and Slinkman E (2006). DNA Fingerprinting and terpenoid analysis of Juniperus blancoi var. huehuentensis (Cupressaceae), a new subalpine variety from Durango, Mexico. Biochem. Syst. Ecol. 34 : 205-211.

Asili A, Behravan J, Naghavi MR and Asili J (2010). Genetic diversity of Persian Shallot (Allium hirtifolium) ecotypes based on morphological traits, allicin content and RAPD markers. Open Access J. Med. Aromatic Plants 1: 1-6.

Emami SA, Asili J, Mohagheghi Z and Hassanzadeh MK (2007). Antioxidant activity of leaves and fruits of Iranian conifers. Evid. Based Complement Alternat. Med. 4: 313-319.

Hojjati F, Zarre S and Assadi M (2009). Isoenzyme diversity and cryptic speciation in Juniperus excelsa (Cupressaceae) complex in Iran. Biochem. Syst. Ecol. 37: 193-200.

Hsiang T and Huang J (2000). The use of RAPD markers to distinguish among Juniper and Cedar cultivars. Can. J. Bot. 78: 655-659.

Nei M and Li WH (1979). Mathematical model for studying genetic variation in terms of restriction endonucleases. Proc. Natl. Acad. Sci. U. S. A. 76: 5269-5273.

Verdu M, Villar-Salvador P and Garcia-Fayos P (2004). Gender effects on the post-facilitation performance of two dioecious Juniperus species. Func. Ecol. 18: 87-93. 